\title{
INTELLECTUAL DYNAMICS OF GOOD GOVERNANCE STUDIES: A BIBLIOMETRIC ANALYSIS
}

\author{
Fauzan $^{1 *}$, Adi Susilo Jahja ${ }^{2}$ \\ ${ }^{1}$ Department of Accountancy, Faculty of Economic and Business, Universitas PGRI Kanjuruhan, \\ Malang, 65148, Indonesia \\ ${ }^{2}$ Department of Management, Faculty of Economics and Business, Perbanas Institute, Jakarta, 12940, \\ Indonesia
}

\begin{tabular}{|c|c|}
\hline ABSTRACT & ARTICLE INFO \\
\hline $\begin{array}{l}\text { Introduction/Main Objectives: This study presents a bibliometric } \\
\text { analysis of good governance research publications from the Scopus } \\
\text { database from } 1984 \text { to } 2020 \text {. Background Problems: Since good } \\
\text { governance has an essential and central role in organizations, the research } \\
\text { trends on good governance in the literature need to be revealed. Novelty: } \\
\text { To the best of our knowledge, bibliometric analysis for the term good } \\
\text { governance is not yet available. This paper aims to fill in the gap by } \\
\text { providing a broad overview of the bibliometric analysis of the literature } \\
\text { relating to this term. Research Methods: Good governance is used as a } \\
\text { keyword in the titles of articles taken from the Scopus database on } \\
\text { November } 4 \text {, 2020. There were } 1,954 \text { documents analyzed. Microsoft } \\
\text { Excel is used for frequency analysis, the VOSviewer app is used for the } \\
\text { data's visualization, and Harzing's Publish or Perish is used for citation } \\
\text { metrics and analysis. Finding/Results: The results showed an increase in } \\
\text { the growth rate of good governance literature from } 1984 \text { to } 2020 \text {, } \\
\text { particularly since } 2011 \text {. Conclusion: Research related to corporate } \\
\text { governance has involved various authors, and is published in various } \\
\text { languages. There are } 159 \text { authors from } 123 \text { countries and } 160 \text { institutions. } \\
\text { The United States is the most significant contributor to this study, } \\
\text { followed by the United Kingdom and Indonesia. The International } \\
\text { Review of Administrative Sciences has published the most papers on } \\
\text { good governance. Our findings indicate that studies on good governance } \\
\text { are mostly carried out in the field of social sciences. }\end{array}$ & $\begin{array}{l}\text { Article information: } \\
\text { Received } 23 \text { November } \\
\text { 2020. Received in } \\
\text { Revised Form } 2 \text { April } \\
\text { 2021. Accepted } 7 \text { April } \\
2021 . \\
\text { Keywords: } \\
\text { bibliometric analysis, } \\
\text { good governance, } \\
\text { intellectual dynamics } \\
\text { JEL Code: } \\
\text { D13, I31, J22, K31 }\end{array}$ \\
\hline
\end{tabular}

\footnotetext{
* Corresponding Author at Department of Accountancy, Faculty of Economic and Business, Universitas PGRI Kanjuruhan, Malang, 65148, Indonesia.

E-mail address: fauzansholeh76@gmail.com (author\#1), adi.susilo@perbanas.id (author\#2)
} 


\section{INTRODUCTION}

Good governance is crucial and occupies a central role in fostering development. Kofi Annan, Secretary-General of the United Nations from 1997 to 2006, said that this concept has a critical role in solving poverty and promoting national development (Abdellatif, 2003). It is a normative term that defines the consistency and sound public administration of democratic choice by respecting economic actors' human rights (Klusáček et al., 2018). In sustainable development and policymaking thinking, good governance is widely discussed (Demmers et al., 2004; Ramzy et al., 2019). Therefore, many countries in the world are following and practicing this concept.

Since this idea is widely accepted, it is investigated in a variety of circumstances. Good governance is conducted to protect individuals and society, administer transparent and efficient public sector policies, and advance social and economic objectives (Addink, 2019). Consequently, good governance is explored in many contexts, using various disciplines and approaches (Addink, 2019; Grindle, 2010; Ramzy et al., 2019). Hence, it is interesting to reveal the intellectual dynamics of this subject.

While previous studies employed a subjective point of view, this study uses an objective approach. Horvath (2017) researched this topic with an analysis of online and printed sources. In his study, he recognized the need for subjectivity in interpreting the texts to make an analytical framework. Schiehll and Martins (2017) conducted critical systematic reviews to screen the articles and evaluate each associated study using filtering techniques. Although somewhat subjective, these studies were conducted in a justified way. Unlike previous studies, this study was implemented using an objective approach. There is little attention paid to the study of good governance using bibliometric analysis (Naomi et al., 2020). A bibliometric analysis enables a more transparent and reproducible process. In this paper, bibliometric analysis is used to capture the evolution of the study of good governance. Accordingly, this study aims to investigate the trends and research developments in the field of good governance.

Bibliometric analysis of the literature relating to this term is used to answer the following questions.

1. How are articles of good governance classified?

2. What is the trend in good governance research?

This paper consists of the following sections. Section 1 is devoted to the introduction. Section 2 explains the overview of the good governance literature based on the previous research and the research objectives. Section 3 describes the methodology used to perform the bibliometric analysis, including the step-by-step method associated with retrieving documents from the Scopus database and using the VOSviewer software and Harzing's Publish or Perish. Section 4 presents the results using VOSviewer and Harzing's Publish or Perish. The conclusions and suggestions appear in Section 5.

\section{LITERATURE REVIEW}

Initially, good governance is conditional on aid It is a requirement for countries that want to get policy advice, financial support, and technical assistance from the World Bank, IMF, and other donor institutions (Dijkstra, 2018; Mohamoud, 2020). The World Bank has endorsed this idea since 1992 (Mohamoud, 2020). According to this institution, underdevelopment and state failures should be overcome by solving the root causes: maladministration, mismanagement, and corruption (Addink, 2019; Mohamoud, 2020). Good governance is supposed to contribute to a 
transparent public administration, efficient public services, and a reliable justice system (Gisselquist, 2012). Therefore, this concept is critical.

Although this concept is crucial, however, there is no consensus on its definition. The literature on governance provides a plethora of definitions (Khouya \& Benabdelhadi, 2020), where the meanings of this concept differ across organizations and contexts (Pomeranz \& Stedman, 2020). Different researchers highlight various aspects of the issue, depending on the topic under study (Tarverdi et al., 2019). Thus, there is no agreed definition of governance (Abdulazeez, 2014; Fukuyama, 2016; Mohamoud, 2020) that provides a convenient device for organizing the literature (Gisselquist, 2012). In this regard, Biswas et al. (2019) opined that Fukuyama (2013) offers a more generalized and clear definition of good governance, which is: the government's capacity to establish and implement laws and provide services. The idea of good governance arose from this viewpoint and became a strategy for sustainable development (Ramzy et al., 2019).

Good governance is needed to ensure the success of sustainable development. Sustainable development aims to satisfy the present's needs without sacrificing the future generations' ability to meet their needs (Brundtland, 1987). In this regard, the United Nations Development Programme (2015) declared the concept of Sustainable Development Goals (SDG's) in 2015. This agenda is a plan for ending poverty and hunger, protecting the earth from degradation, ensuring human prosperity, and fostering a peaceful, just and inclusive society. These plans are implemented through global partnerships. In short, this agenda is an action plan for people, planet, prosperity, peace, and partnership. Goal no. 16 of the SDGs asserts the importance of strong institutions to ensure the effectiveness of supporting and promoting sustainable development. Therefore, good governance is one of the foundations for sustainable development.

Consequently, good governance is related to many dimensions of development. In this regard, good governance is inextricably linked to the economic, environmental, social, and political dimensions (Abdulazeez, 2014; Dhaoui, 2019; Ramzy et al., 2019). The economic dimension emphasizes governments' effectiveness and capacity to utilize scarce resources to meet people's wants continuously. The environmental dimension emphasizes the environmental protection for future generations from the depletion of non-renewable resources and renewable resources' over-exploitation. The social dimension ensures that all communities in society act and function without discrimination, achieving distributional equality, gender equity, and providing sufficient social services, including education, health, and political accountability. The political dimension denotes the responsibility of the government's political elements, the lawfulness of the government, and respect for human rights. Therefore, good governance encompasses a wide variety of research areas.

Previous studies revealed that governance is the subject of discussion in many fields. Addink (2019) stated that theologians, philosophers, social scientists, economists, and lawyers all have different perspectives on good governance. Each discipline contributes to constructing the understanding of good governance, bringing the most significant possible benefits to society. Likewise, Burris et al. (2008) pointed out the considerable overlap across diverse fields of study. Horvath (2017) supported their view and emphasized that none of the areas are mutually exclusive. He also revealed that governance was studied frequently in the following academic 
fields: international relations, political science, management studies, business studies, economics, (international) law, public policy/administration, development studies, and higher education studies. Hence, good governance is a cross-disciplinary study.

To summarize, since good governance is essential for sustainable development, many countries have adopted it. A comprehensive understanding of the various dimensions of development is needed to implement sustainable development. Consequently, the good governance literature cuts across disciplinary boundaries. On the other hand, this concept's definition has not been agreed upon; therefore, good governance is open to further discussions.

\section{METHOD, DATA, AND ANALYSIS}

Bibliometric analysis is employed toward all journal articles in the leading Scopus database. The advantages of the bibliometric method are in terms of its quantification and objectivity. Bibliometric analysis can avoid some of the subjective bias potentials and can confirm what experts in the field can infer intuitively. Since good governance is a multidisciplinary area that openly borrows and assimilates work from different disciplines, long-term bibliometric research may help recognize the most influential works and their relationships. This study shows the research trends, the language used, the affiliations, the authors' countries, searches for citations in articles, identifying how these quotes relate to various good governance research topics, and how shared citation patterns have developed.

\section{Bibliometric analysis}

Bibliometric is "the application of mathematics and statistical methods to books and other media of communication" (Pritchard, 1969). According to Potter (1981), bibliometric measures publi- cation patterns and written communications and authorship modes. It is also the use of quantitative and statistical analysis to describe the patterns of publication in particular scientific literature (Bellis, 2009; Ma, 2005), it measures text and information, and makes it possible to analyze published documents (Daim et al., 2006; Hall, 2011). This method is a popular method for uncovering trends in the research articles being studied (Ahmi \& Mohamad, 2019). Additionally, it can be used in evaluating the quantity and quality of published material to monitor trends or patterns in a particular research area (Sweileh et al., 2017). Bibliometric analysis can also provide descriptive patterns of publications by domain, field, country, and period (Ho, 2007). Finally, bibliometric analysis can provide more detailed information regarding a publication, including the author, the keyword frequency, and citations (Rusly et al., 2019). Thus, the bibliometric method can reveal and analyze the impact of literature on each scientific discipline and help formulate policies for various studies, publishers' ratings, literature developments, collection developments, and other related policies.

\section{Source and data collection}

The unit of analysis adopted is granular, which includes all scientific works in the Scopus database on good governance, published from 1984 to 2020. Determination of this period follows the Scopus database. The year good governance studies were written and indexed by the Scopus database can be identified by including all the years. Harzing's Publish and Perish revealed that the first study on good governance indexed by the Scopus database was authored by Silal et al. (1984).

Data are collected to map the good governance studies' conceptual framework, including qualitative, quantitative, case studies, non- 
empirical, and others in the published Scopus database. A search query (TITLE (good governance)) was applied to article titles in the Scopus database on November 4, 2020, at 7.58 am. This query produced a total of 1,954 documents for further analysis. The data set were exported in CSV (comma separated values) and RIS (research information system) formats. Microsoft Excel, VOSviewer, and Harzing's Publish or Perish have been used to analyze the submitted documents. These steps are depicted in Figure 1.

\section{RESULTS AND DISCUSSION}

Some general statistics from the data set are presented to get an overview of the research related to good governance. All the articles that met the search query were evaluated from the following aspects: document type and source, research productivity, publication language, subject area, most active source titles, distribution of publications by country, most active institutions, authorship, keywords, title, and abstract analysis and citation analysis.

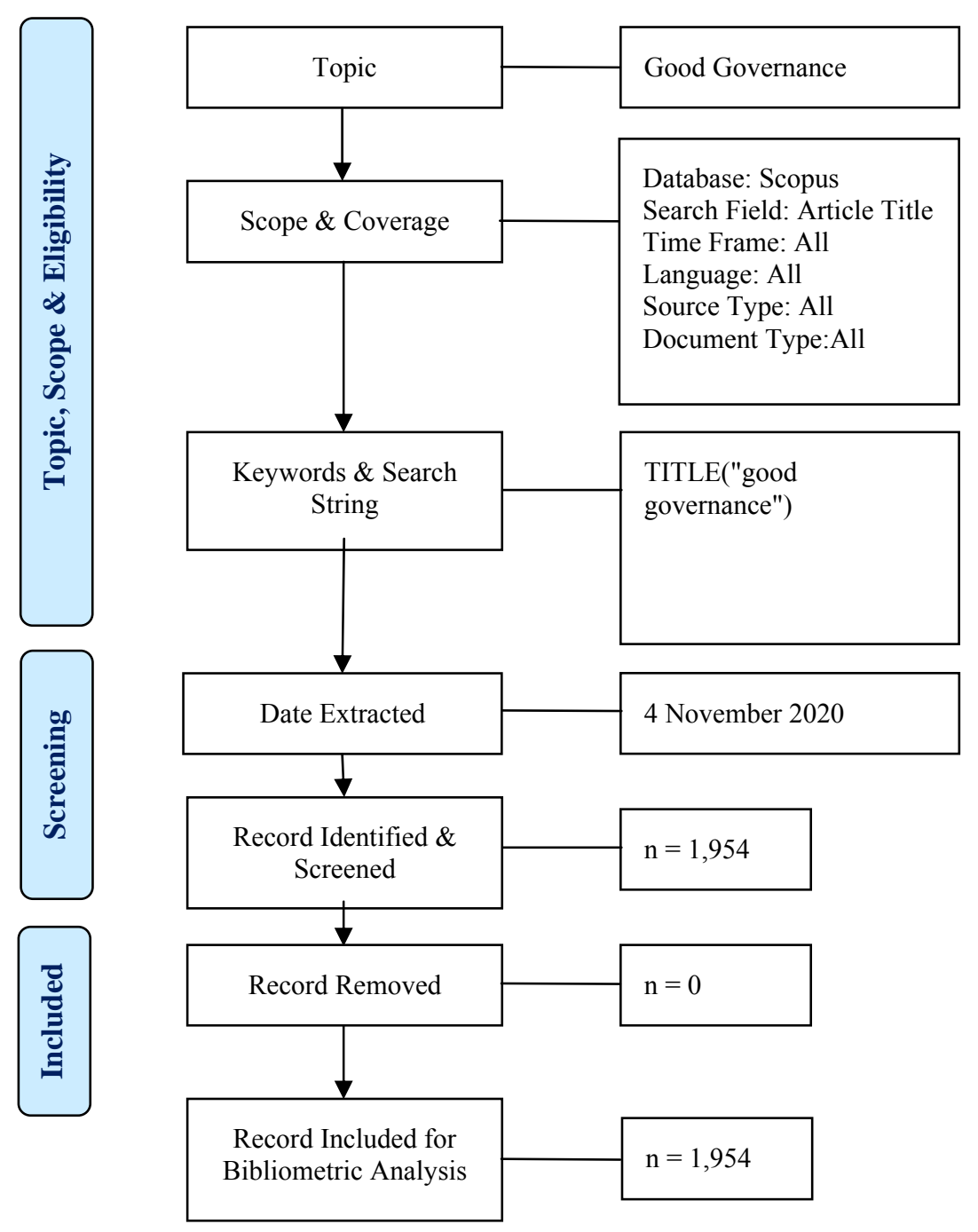

Source: Zakaria et al. (2021)

Figure 1. Flow diagram of the search strategy 
Most of the results are presented in terms of frequency and percentage. We show annual growth data as the number of documents generated each year, including frequency, percentage, and cumulative percentage. We report the citation analysis as a citation metric and reveal the 10 most cited articles on good governance.

\section{Document and Source Types}

Types of documents are documents based on the authenticity of documents from articles, conference papers, and book chapters. Source documents are documents in journals, conference proceedings, books, book series, and trade publications. According to Sweileh et al. (2017), conference papers that appear under document types may vary from those that appear under source documents. For instance, a paper delivered at a conference is classified as a conference paper under the document types. However, the same paper can be classified as a full journal article, conference proceedings, or book chapter under documentary sources, depending on its publication status.

Table 1. Document type

\begin{tabular}{lcc}
\hline Document Type & Frequency & \% (N=1,954) \\
\hline Article & 1,217 & 62.28 \\
Book Chapter & 333 & 17.04 \\
Conference Paper & 157 & 8.03 \\
Review & 89 & 4.55 \\
Book & 55 & 2.81 \\
Editorial & 42 & 2.15 \\
Note & 34 & 1.74 \\
Letter & 11 & 0.56 \\
Short Survey & 11 & 0.56 \\
Erratum & 4 & 0.20 \\
Conference Review & 1 & 0.05 \\
\hline Total & $\mathbf{1 , 9 5 4}$ & $\mathbf{1 0 0 . 0 0}$ \\
\hline
\end{tabular}

As summarized in Table 1, publications on good governance are spread over 11 types of documents. More than half of the total publications are articles, consisting of 1,217 documents (62.28\%). Moreover, as presented in Table 2, documents are classified into five types of sources: journals, books, conference proceedings, book series, trade journals, and one source that cannot be identified. Based on Table 2 , journals are the highest source documents, with 1,411 documents representing $72.21 \%$ of the total publications.

Table 2. Source type

\begin{tabular}{lcc}
\hline Source Type & Frequency & \% $(\mathbf{N}=\mathbf{1 , 9 5 4 )}$ \\
\hline Journal & 1,411 & 72.21 \\
Book & 380 & 19.45 \\
Conference Proceeding & 113 & 5.78 \\
Book Series & 38 & 1.94 \\
Trade Journal & 11 & 0.56 \\
Undefined & 1 & 0.05 \\
\hline Total & $\mathbf{1 , 9 5 4}$ & $\mathbf{1 0 0 . 0 0}$ \\
\hline
\end{tabular}

\section{Year of Publications - Evolution of Published Studies}

This first analysis examines the research productivity based on the number of documents published per year. A review of the documents by year of publication helps researchers observe the patterns and popularity of research subjects over time. The first publication on good governance was written by Silal et al. (1984) with the title "From e-government to good governance: The mediating role of government e-participation." Subsequently, the growth of publications has continued to increase until 2020. The drastic increase in the number of publications on good governance began in 2011, which reached 100 and continues to fluctuate until now (see Figure 2). Table 3 summarizes the details of the number of good governance publications since 1984. Based on the number of publications, good governance still seems to be a favorite topic among academics. 


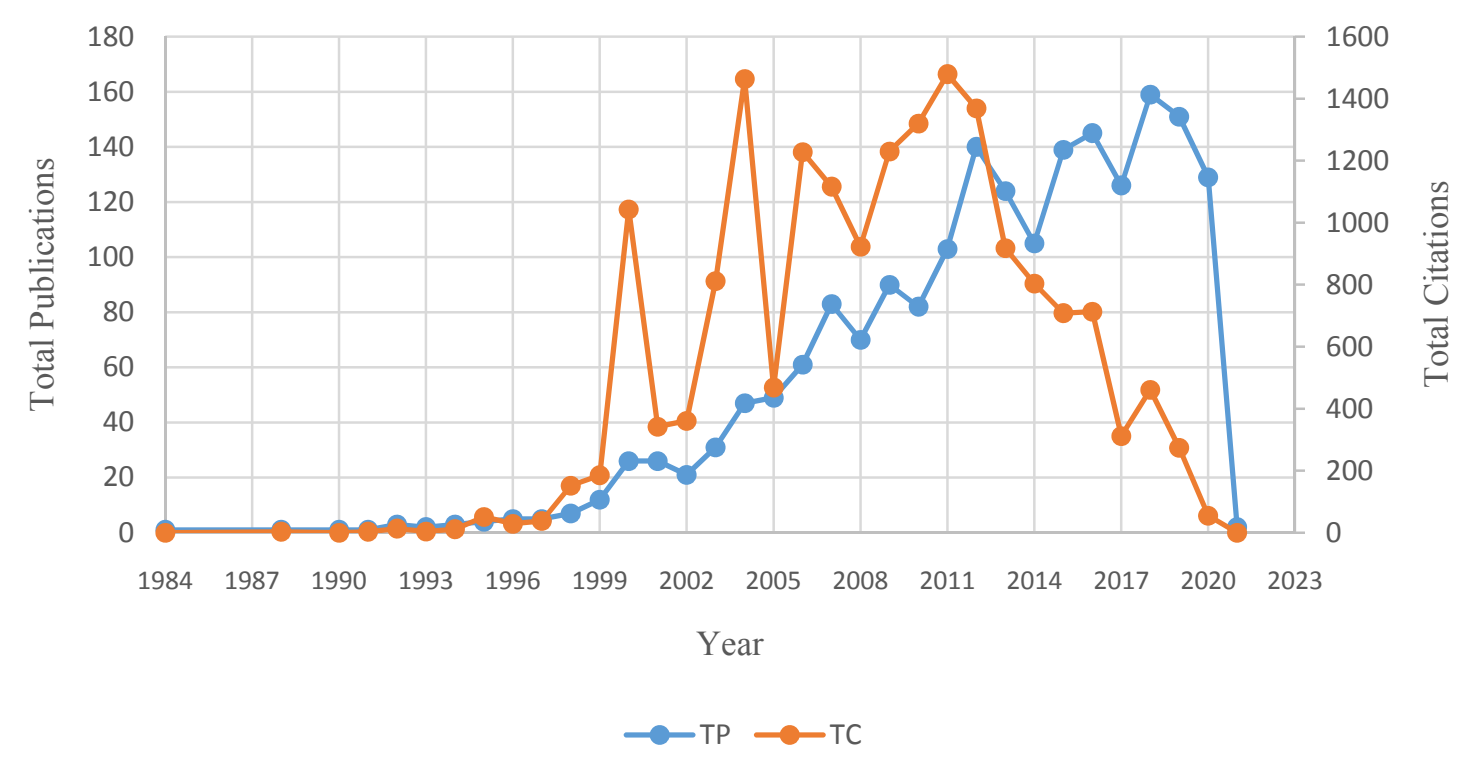

Figure 2. Total publications and citations by year

The highest number of citations per year occurred in 2011, with 1,479 citations per year and 103 documents published. The second position for the number of citations per year was 1,464 in 2004 with 47 documents. Meanwhile, in
2012 the number of citations per year was 1,369 , with the number of publications being 140 documents. Table 3 presents the data on the total publications and citations per year.

Table 3. Year of publication

\begin{tabular}{cccccccc}
\hline Year & TP & NCP & TC & C/P & C/CP & $\boldsymbol{h}$ & $\boldsymbol{g}$ \\
\hline 1984 & 1 & 0 & 0 & 0 & 0 & 0 & 0 \\
1988 & 1 & 1 & 3 & 3.00 & 3.00 & 1 & 1 \\
1990 & 1 & 0 & 0 & 0 & 0 & 0 & 0 \\
1991 & 1 & 1 & 3 & 3.00 & 3.00 & 1 & 1 \\
1992 & 3 & 2 & 13 & 4.33 & 6.50 & 2 & 3 \\
1993 & 2 & 2 & 4 & 2.00 & 2.00 & 1 & 2 \\
1994 & 3 & 3 & 11 & 3.67 & 3.67 & 2 & 3 \\
1995 & 4 & 4 & 51 & 12.75 & 12.75 & 2 & 4 \\
1996 & 5 & 4 & 29 & 5.80 & 7.25 & 3 & 5 \\
1997 & 5 & 5 & 38 & 7.60 & 7.60 & 3 & 5 \\
1998 & 7 & 6 & 152 & 21.71 & 25.33 & 5 & 7 \\
1999 & 12 & 9 & 185 & 15.42 & 20.56 & 7 & 12 \\
2000 & 26 & 23 & 1,043 & 40.12 & 43.35 & 12 & 26 \\
2001 & 26 & 22 & 342 & 13.15 & 15.55 & 8 & 18 \\
2002 & 21 & 13 & 361 & 17.19 & 27.77 & 7 & 19 \\
2003 & 31 & 22 & 812 & 26.19 & 36.91 & 9 & 28 \\
2004 & 47 & 39 & 1,464 & 31.15 & 37.54 & 15 & 38 \\
2005 & 49 & 34 & 468 & 9.55 & 13.76 & 12 & 20 \\
\hline
\end{tabular}




\begin{tabular}{cccccccc}
\hline Year & TP & NCP & TC & C/P & C/CP & $\boldsymbol{h}$ & $\boldsymbol{g}$ \\
\hline 2006 & 61 & 51 & 1,228 & 20.13 & 24.08 & 15 & 34 \\
2007 & 83 & 56 & 1,116 & 13.45 & 19.93 & 16 & 32 \\
2008 & 70 & 57 & 923 & 13.19 & 16.19 & 15 & 28 \\
2009 & 90 & 70 & 1,230 & 13.67 & 17.57 & 16 & 33 \\
2010 & 82 & 62 & 1,320 & 16.1 & 21.29 & 18 & 35 \\
2011 & 103 & 72 & 1,479 & 14.36 & 20.54 & 18 & 37 \\
2012 & 140 & 95 & 1,369 & 9.78 & 14.41 & 19 & 34 \\
2013 & 124 & 90 & 918 & 7.40 & 10.20 & 16 & 26 \\
2014 & 105 & 80 & 804 & 7.66 & 10.05 & 16 & 24 \\
2015 & 139 & 95 & 708 & 5.09 & 7.45 & 12 & 22 \\
2016 & 145 & 87 & 713 & 4.92 & 8.20 & 14 & 22 \\
2017 & 126 & 63 & 312 & 2.48 & 4.95 & 9 & 12 \\
2018 & 159 & 90 & 461 & 2.90 & 5.12 & 12 & 15 \\
2019 & 151 & 70 & 274 & 1.81 & 3.91 & 8 & 13 \\
2020 & 129 & 28 & 55 & 0.43 & 1.96 & 4 & 4 \\
2021 & 2 & 0 & 0 & 0 & 0 & 0 & 0 \\
\hline Total & $\mathbf{1 , 9 5 4}$ & \multicolumn{5}{l}{} & \\
\hline Notes: TP=total number of publications; NCP=number of cited publications; TC=total citations; C/P=average citations per \\
publication; C/CP=average citations per cited publication; $\mathrm{h}=\mathrm{h}$-index; and g=g-index.
\end{tabular}

\section{Languages of the Documents}

As presented in Table 4, English was the commonly used language in the collected publications, found in $95.04 \%$ of the total documents. Several publications were also published in French, Spanish, and German, and other languages. There were also 23 bilingual documents.

\section{Subject Area}

This study also categorized the publications based on the subject areas summarized in Table 5. Since good governance focuses more on social science, business, and economics, those three fields of study occupied the top rank for the number of publications. Other areas that made significant contributions are environmental science, the arts and humanities, medicine, computer science, and engineering.
Table 4. Languages used for publications

\begin{tabular}{lcc}
\hline Language & Total Publication & \% $\mathbf{( N = 1 , 9 7 7 )}$ \\
\hline English & 1,879 & 95.04 \\
French & 34 & 1.72 \\
Spanish & 28 & 1.42 \\
German & 10 & 0.51 \\
Portuguese & 9 & 0.46 \\
Italian & 4 & 0.20 \\
Lithuanian & 2 & 0.10 \\
Persian & 2 & 0.10 \\
Arabic & 1 & 0.05 \\
Chinese & 1 & 0.05 \\
Croatian & 1 & 0.05 \\
Czech & 1 & 0.05 \\
Dutch & 1 & 0.05 \\
Russian & 1 & 0.05 \\
Slovak & 1 & 0.05 \\
Swedish & 1 & 0.05 \\
Thai & 1 & 0.05 \\
\hline Total & $\mathbf{1 , 9 7 7}$ & $\mathbf{1 0 0 . 0 0}$ \\
\hline
\end{tabular}

*23 documents were in dual languages 
Table 5. Subject area

\begin{tabular}{|c|c|c|}
\hline Subject Area & Total Publication & $\%(N=3,155)$ \\
\hline Social Sciences & 1,140 & 36.13 \\
\hline Business, Management, and Accounting & 471 & 14.93 \\
\hline Economics, Econometrics, and Finance & 372 & 11.79 \\
\hline Environmental Science & 211 & 6.69 \\
\hline Arts and Humanities & 174 & 5.52 \\
\hline Medicine & 139 & 4.41 \\
\hline Computer Science & 137 & 4.34 \\
\hline Engineering & 133 & 4.22 \\
\hline Agricultural and Biological Sciences & 93 & 2.95 \\
\hline Earth and Planetary Sciences & 48 & 1.52 \\
\hline Decision Sciences Journal & 45 & 1.43 \\
\hline Energy & 37 & 1.17 \\
\hline Nursing & 22 & 0.70 \\
\hline Mathematics & 20 & 0.63 \\
\hline Biochemistry, Genetics and Molecular Biology & 18 & 0.57 \\
\hline Materials Science & 15 & 0.48 \\
\hline Multidisciplinary & 15 & 0.48 \\
\hline Physics and Astronomy & 12 & 0.38 \\
\hline Psychology & 12 & 0.38 \\
\hline Pharmacology, Toxicology, and Pharmaceutics & 10 & 0.32 \\
\hline Chemical Engineering & 9 & 0.29 \\
\hline Immunology and Microbiology & 7 & 0.22 \\
\hline Health Professions & 6 & 0.19 \\
\hline Chemistry & 5 & 0.16 \\
\hline Veterinary & 3 & 0.10 \\
\hline Neuroscience & 1 & 0.03 \\
\hline Total & 3,155 & 100.00 \\
\hline
\end{tabular}

\section{The Most Active Source Titles}

This research also presents the most active source titles with eight or more publications on good governance. Table 6 provides information about the publishers, and the International Review of Administrative Sciences is the top publisher, with 16 articles about good governance (2.31\%).

\section{Keywords Analysis}

We map the keywords provided in each document using VOSviewer. VOSviewer is a powerful network analysis software tool that helps visualize the dynamics and structure of science, it can couple events together through a keyword analysis for in-depth exploration, and examine the intellectual structure of the intended research area (Valenzuela et al., 2017; van Eck \& Waltman, 2010). The keywords were mapped using VOSviewer. Figure 3 demonstrates a network visualization of the authors' keywords, that is, good governance. This figure indicates the strength of the relationship between the keywords by the color, circle size, font size, and line thickness (Sweileh et al., 2017).

Based on the analysis, there are four clusters of good governance research that have been developed based on the keywords. The first 
cluster, colored red, relates to a governance approach and good governance. Likewise, the other clusters are colored green, blue, and yellow.

Subsequently, the latest research topics can be seen in Figure 4. The yellow color shows the issues investigated by recent research into good governance. Figure 4 is no different from Figure 3 ; Figure 4 is colored according to the research's publication date.

Table 6. The most active source title

\begin{tabular}{lcc}
\hline \multicolumn{1}{c}{ Source Title } & Total Publication & \% (N=692) \\
\hline International Review of Administrative Sciences & 16 & 2.31 \\
Corporate Ownership and Control & 14 & 2.02 \\
International Journal of Innovation Creativity and Change & 14 & 2.02 \\
OIE Revue Scientifique Et Technique & 14 & 2.02 \\
Trustee the Journal for Hospital Governing Boards & 11 & 1.59 \\
ACM International Conference Proceeding Series & 10 & 1.45 \\
Corporate Governance an International Review & 10 & 1.45 \\
Journal of Advanced Research in Dynamical and Control Systems & 10 & 1.45 \\
Mediterranean Journal of Social Sciences & 10 & 1.45 \\
Asian Social Science & 9 & 1.30 \\
Corporate Governance Bingley & 9 & 1.30 \\
Quest for Good Urban Governance: Theoretical Reflections and & & \\
International Practices & 9 & 1.30 \\
International Journal of Public Administration & 8 & 1.16 \\
International Journal of Scientific and Technology Research & 8 & 1.16 \\
Journal of Business Ethics & 8 & 1.16 \\
Public Administration and Development & 8 & 1.16 \\
Regulation and Governance & 8 & 1.16 \\
Third World Quarterly & 8 & 1.16 \\
World Development & 8 & 1.16 \\
\hline
\end{tabular}




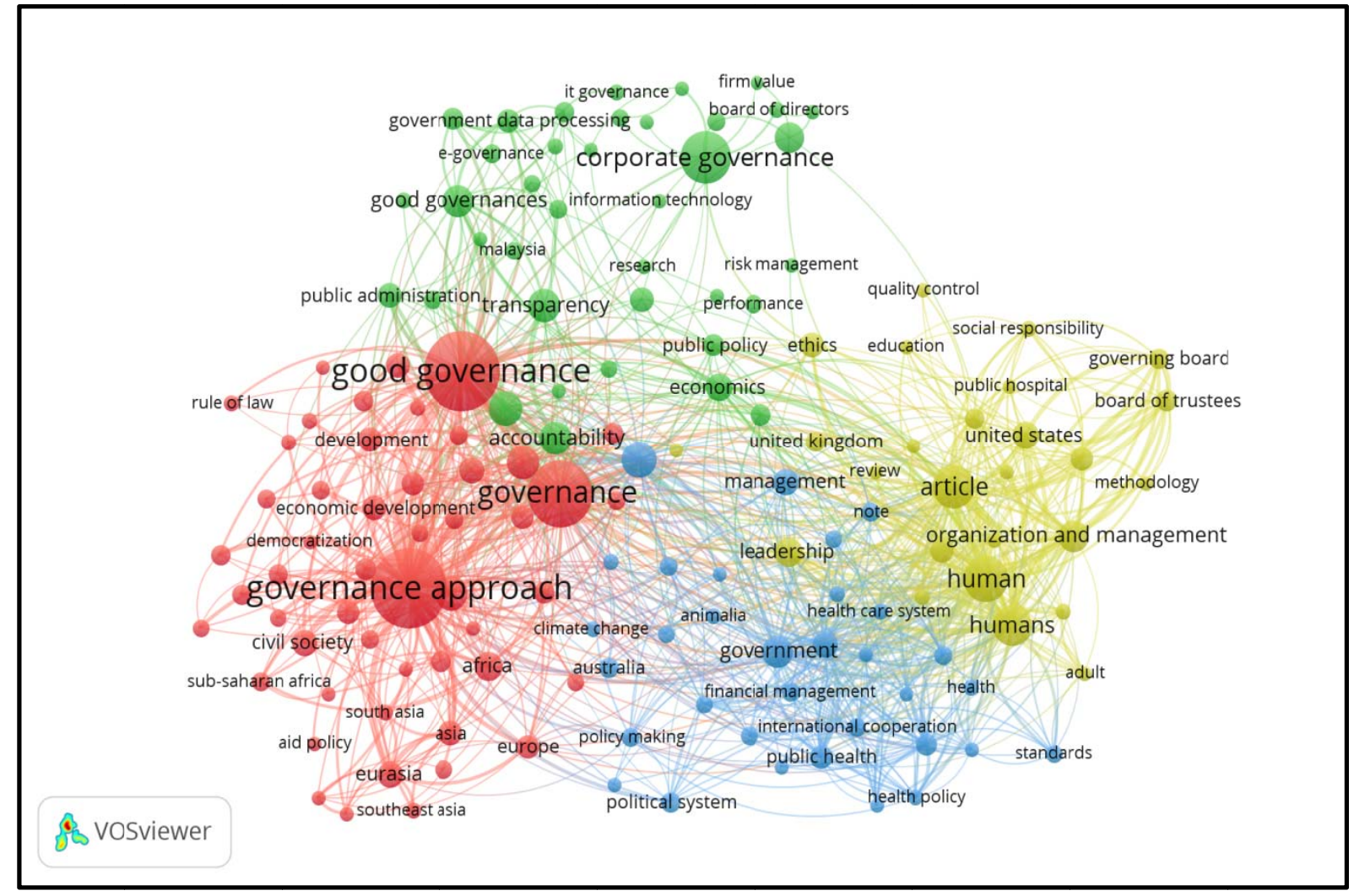

Source: VOSviewer

Figure 3. Network visualization map of the author keywords

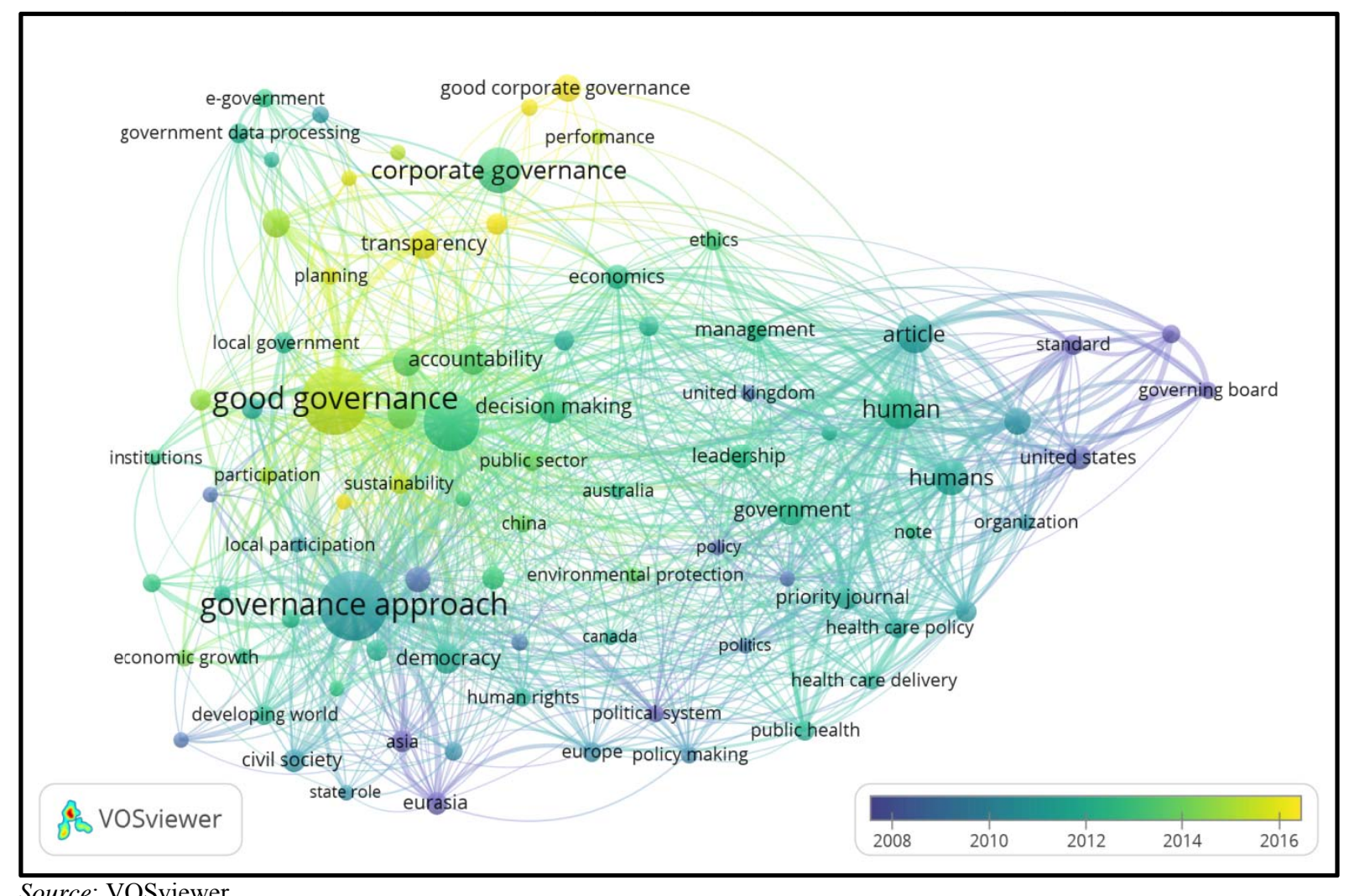

Source: VOSviewer

Figure 4. Overlay visualization map of the author keywords 
We also analyzed the keywords in the spreadsheet document to calculate the total number of occurrences. Based on Figure 3, Table 7 exhibits the total frequency of keywords used from the documents taken. This keyword analysis resulted in 148 interconnected items gathered in four clusters (red, green, blue, and yellow) and 160 keywords had been used.

Table 7. Articles with their most frequently occurring keywords

\begin{tabular}{|c|c|c|}
\hline Cluster & $\begin{array}{c}\text { Most frequent } \\
\text { keywords }\end{array}$ & Keywords \\
\hline $\begin{array}{l}\text { Cluster one - Red } \\
\text { (51keywords) }\end{array}$ & $\begin{array}{l}\text { "Governance } \\
\text { Approach" ( } 293 \\
\text { occurrences); "Good } \\
\text { Governance" (288); } \\
\text { "Governance" (205). }\end{array}$ & $\begin{array}{l}\text { Africa, aid policy, Asia, Bangladesh, Canada, China, civil } \\
\text { society, corruption, decentralization, democracy, democratiza- } \\
\text { tion, developing world, development, Eastern Hemisphere, } \\
\text { economic development, economic growth, Eurasia, Europe, } \\
\text { European Union, human rights, India, innovation, institutional } \\
\text { framework, institutions, land management, local government, } \\
\text { local participation, deliberalism, non-governmental organization, } \\
\text { participation, participatory approach, policy implementation, } \\
\text { political economy, poverty alleviation, public sector, rule of law, } \\
\text { South Africa, South Asia, Southeast Asia, stakeholder, state role, } \\
\text { sub-Saharan Africa, sustainability, theoretical study, urban } \\
\text { planning, water management, world, World Bank. }\end{array}$ \\
\hline $\begin{array}{l}\text { Cluster two - } \\
\text { Green ( } 38 \\
\text { keywords) }\end{array}$ & $\begin{array}{l}\text { "Corporate } \\
\text { Governance" (126 } \\
\text { occurrences); } \\
\text { "Sustainable } \\
\text { Development" (58); } \\
\text { "Transparency" (53). }\end{array}$ & $\begin{array}{l}\text { Accountability, audit committee, best practice, best practices, } \\
\text { board of directors, corporate social responsibility, developing } \\
\text { countries, e-governance, e-government, economic and social } \\
\text { effect, economics, firm value, globalization, good corporate } \\
\text { governance, good governances, government data processing, } \\
\text { Indonesia, industrial management, information and } \\
\text { communication technologies, information management, } \\
\text { information systems, information technology, integrity, IT } \\
\text { governance, Malaysia, perception, performance planning, public } \\
\text { administration, public policy, research, risk management, } \\
\text { societies and institution, surveys, trust. }\end{array}$ \\
\hline $\begin{array}{l}\text { Cluster three - } \\
\text { Blue (33 } \\
\text { keywords) }\end{array}$ & $\begin{array}{l}\text { "Decision Making" (59 } \\
\text { occurrences); } \\
\text { "Government" (49) }\end{array}$ & $\begin{array}{l}\text { Animalia, Australia, climate change, delivery of health care, } \\
\text { developing country, environmental management, environmental } \\
\text { policy, environmental protection, financial management, } \\
\text { government regulation, health, health care delivery, health care } \\
\text { organization, health care policy, health care system, health } \\
\text { policy, international cooperation, investment, law, management, } \\
\text { note, policy, policymaking, political system, politics, priority } \\
\text { journal, procedures, public health, resource management, } \\
\text { standard, United Nations. }\end{array}$ \\
\hline $\begin{array}{l}\text { Cluster four - } \\
\text { Yellow ( } 26 \\
\text { keywords) }\end{array}$ & $\begin{array}{l}\text { "Human" (101 } \\
\text { occurrences); "Article" } \\
\text { (89); "Humans" (79). }\end{array}$ & $\begin{array}{l}\text { Adult, board of trustees, capacity building, education, ethics, } \\
\text { female, governing board, health care quality, health service, } \\
\text { leadership, medical research, methodology, national health } \\
\text { service, organization, organization and management, practice } \\
\text { guideline, public hospital, quality control, review, social } \\
\text { responsibility, standard, United Kingdom, United States. }\end{array}$ \\
\hline
\end{tabular}


Based on Table 7, we sorted the top keywords as shown in the next table.

Table 8: Top Keywords

\begin{tabular}{lcc}
\hline \multicolumn{1}{c}{ Keywords } & $\begin{array}{c}\text { Total } \\
\text { Keywords }\end{array}$ & $\begin{array}{c}\text { \% } \\
(\mathbf{N = 4 , 0 7 9 )}\end{array}$ \\
\hline 1. Governance Approach & 293 & 7.18 \\
2. Good Governance & 288 & 7.06 \\
3. Governance & 205 & 5.03 \\
4. Corporate Governance & 126 & 3.09 \\
5. Human & 101 & 2.48 \\
6. Article & 89 & 2.18 \\
7. Article & 89 & 2.18 \\
8. Humans & 79 & 1.94 \\
9. Decision Making & 59 & 1.45 \\
10. Democracy & 58 & 1.42 \\
11. Sustainable & 58 & 1.42 \\
$\quad$ Development & & \\
12. Transparency & 53 & 1.30 \\
13. Government & 49 & 1.20 \\
\hline
\end{tabular}

\section{Title and abstract analysis}

This study examined the titles and abstracts of the documents collected based on the number of occurrences and co-occurrences using VOSviewer. In particular, this analysis used the binary count method in the construction of a coevent network. A binary counting methodology means the number of times a noun phrase appears in a publication's title, but not in the abstract. Noun phrases that appear only once in a publication's title and abstract are handled in the same way as a noun phrase that happens 10 times (van Eck \& Waltman, 2010).

Figure 5 displays the term co-occurring network's visualization of the keywords by title and abstract with the minimum number of occurrences of the terms. It is important to note that this figure is different from the previous figures. In figures 4 and 5, the keywords are based on title only. If Figure 5 is described in tabular form, the results will not be much different from Table 7.

Figure 5 reveals good governance as the main term that acts as the central node of the entire network in good governance research. The nodes' size shows the weight of the occurrence, while the thickness of the connecting lines shows the strength of the relationship between terms. Related words, such as those shown in the same color, often appear together. For example, the diagram indicates that good governance, participation, process, capacity, state, reform, right, law, region, rule, challenge, and other terms colored in red are closely related and usually appear together. Specifically, VOSviewer generated four different colors representing the four clusters with 109 terms from the publication title, 5,666 links, and total link strength of 73,875 .

\section{Geographical Distribution of Publications}

The study also evaluates the number of publications by country, based on the authors' affiliations. Overall, a total of 123 countries were identified as being involved in good governance publications. Table 9 presents the top active countries that contributed at least 20 publications on good governance. The United States contributed the highest number of publications (294), representing $12.56 \%$ of the total publications in good governance, followed by the United Kingdom (9.79\%), Indonesia (7.44\%), Australia (5.24\%), and Canada (4.62\%). These results indicate that developed countries occupy a leading position in good governance research, compared to developing countries. 


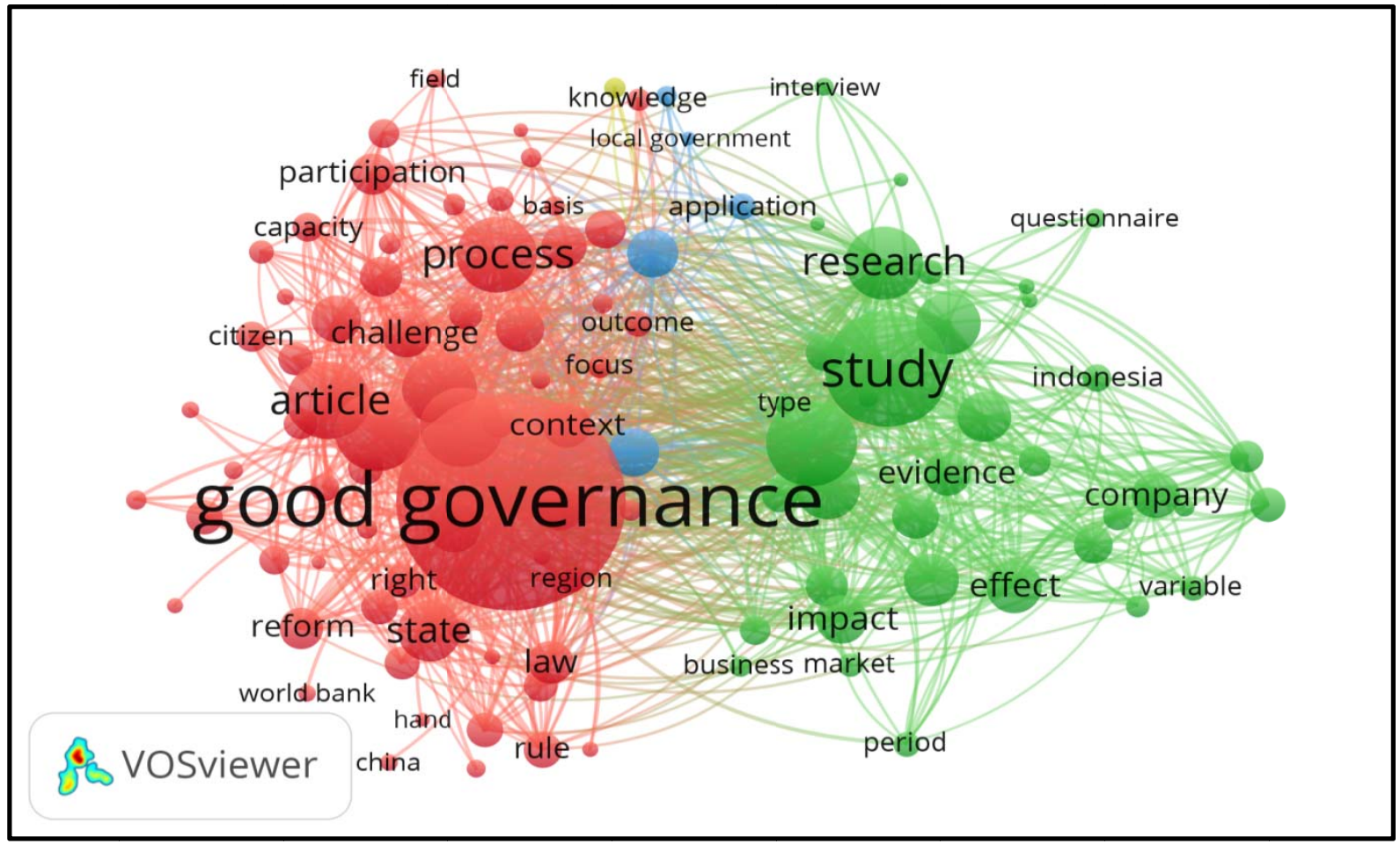

Source: VOSviewer

Figure 5. VOSviewer visualization of a term co-occurrence network based on title and abstract fields

Table 9. Top 20 countries contributing to the

\begin{tabular}{lcc}
\multicolumn{3}{c}{ publications } \\
\hline \multicolumn{1}{c}{ Country } & $\begin{array}{c}\text { Total } \\
\text { Publication }\end{array}$ & \% (N=2,340) \\
\hline United States & 294 & 12.56 \\
United Kingdom & 229 & 9.79 \\
Indonesia & 174 & 7.44 \\
Australia & 117 & 5.00 \\
Canada & 108 & 4.62 \\
Netherlands & 95 & 4.06 \\
Germany & 91 & 3.89 \\
South Africa & 68 & 2.91 \\
India & 63 & 2.69 \\
Malaysia & 57 & 2.44 \\
France & 50 & 2.14 \\
Italy & 46 & 1.97 \\
Spain & 45 & 1.92 \\
Belgium & 36 & 1.54 \\
China & 35 & 1.50 \\
Switzerland & 33 & 1.41 \\
Nigeria & 29 & 1.24 \\
Thailand & 29 & 1.24 \\
Norway & 25 & 1.07 \\
Iran & 24 & 1.03 \\
\hline & &
\end{tabular}

\section{Authors Analysis}

For analyzing the authors, Harzing's Publish or Perish application was used to map the number of authors, the most productive authors, their affiliations, and citations. Based on Harzing's Publish or Perish analysis, 159 unique authors contributed 1,954 publications on good governance. Table 10 presents the number of publications based on the number of authors for each publication. According to the table, $49.54 \%$ of the publications were single-authored, while the rest were multi-authored. Most of the multiauthored articles on good governance were coauthored by either two authors $(25.23 \%)$ or three authors (12.49\%). The highest number of authors writing publications on good governance was 26 .

This study revealed the most active authors who publish documents on good governance. Table 11 lists the most active authors with a minimum of four publications. As indicated in the table, M.S. Grindle, affiliated with Harvard University, in the United States, is the most 
active author in this field of study, having five pieces on good governance published. He also has a total citation of 968 , an h-index of five and a g-index of five, the largest number of citations and indexes.

Table 10. Number of author(s) per document

\begin{tabular}{ccc}
\hline Author Count & Total Publication & \% $\mathbf{( N = 1 , 9 5 4 )}$ \\
\hline 1 & 968 & 49.54 \\
2 & 493 & 25.23 \\
3 & 244 & 12.49 \\
4 & 119 & 6.09 \\
5 & 47 & 2.41 \\
6 & 25 & 1.28 \\
7 & 8 & 0.41 \\
8 & 11 & 0.56 \\
9 & 4 & 0.20 \\
10 & 4 & 0.20 \\
11 & 1 & 0.05 \\
12 & 1 & 0.05 \\
13 & 1 & 0.05 \\
14 & 1 & 0.05 \\
15 & 1 & 0.05 \\
18 & 1 & 0.05 \\
26 & 1 & 0.05 \\
$0 *$ & 24 & 1.23 \\
\hline Total & $\mathbf{1 , 9 5 4}$ &
\end{tabular}

Table 11. Most productive authors

\begin{tabular}{|c|c|c|c|c|c|c|c|c|c|}
\hline Author's Name & Affiliation & Country & $\mathbf{T P}$ & NCP & TC & $\mathbf{C} / \mathbf{P}$ & $\mathrm{C} / \mathrm{CP}$ & h & g \\
\hline Grindle, MS. & Harvard University & United States & 5 & 5 & 968 & 193.6 & 193.6 & 5 & 5 \\
\hline Mungiu-Pippidi, A. & $\begin{array}{l}\text { Hertie School of } \\
\text { Governance GmbH }\end{array}$ & German & 5 & 5 & 120 & 24 & 24 & 3 & 5 \\
\hline Aguilera, R.V. & $\begin{array}{l}\text { Northeastern } \\
\text { University }\end{array}$ & United States & 4 & 4 & 576 & 144 & 144 & 4 & 4 \\
\hline Cuervo-Cazurra, A. & $\begin{array}{l}\text { Northeastern } \\
\text { University }\end{array}$ & United States & 4 & 4 & 576 & 144 & 144 & 4 & 4 \\
\hline Brinkerhoff, D.W. & RTI International & United States & 4 & 4 & 296 & 74 & 74 & 4 & 4 \\
\hline Hendriks, F. & Tilburg University & Netherlands & 4 & 3 & 39 & 9.75 & 13 & 2 & 4 \\
\hline Kettani, D. & $\begin{array}{l}\text { Al Akhawayn } \\
\text { University }\end{array}$ & Morocco & 4 & 3 & 8 & 2 & 2.67 & 2 & 2 \\
\hline Schaap, L. & Tilburg University & Netherlands & 4 & 3 & 8 & 2 & 2.67 & 2 & 2 \\
\hline Turnbull, S. & $\begin{array}{l}\text { International Institute } \\
\text { for Sel-governance }\end{array}$ & Australia & 4 & 2 & 8 & 2 & 4 & 2 & 2 \\
\hline Levi-Faur, D. & $\begin{array}{l}\text { Hebrew University of } \\
\text { Jerusalem }\end{array}$ & Israel & 4 & 0 & 0 & 0 & 0 & 0 & 0 \\
\hline
\end{tabular}


This study analyzed author collaborations by conducting a co-author analysis using VOSviewer. This analysis is based on influential authors who have more than five citations and are counted using the full count method. The color, size of the circle, size of the font, and thickness of the connecting lines indicate the relationships between the authors. Connected authors, as shown in the same color, are usually grouped. Based on the visualization produced by VOSviewer, there were only two authors who collaborated in their research. They are CuervoCazurra and Aguilera (shown in red) and Hendriks and Schaap (shown in green), while the other writers who appear in the diagram did not collaborate (see Figure 6). In Figure 6, there are
11 items with nine clusters, and there are two links with a total link strength of seven.

Figure 7 shows more about the network's visualization map of the authors by their countries of affiliation. Only countries with more than five articles and more than one citation were considered in this analysis. Based on the full count method, these findings suggest that the United States plays a very prominent role in cooperating with other countries. The United States has worked closely with Hong Kong, Iran, and Finland, while the United Kingdom works closely with Israel, Romania, and the United Arab Emirates. Figure 7 shows a map of the network visualization of co-authoring by country, with at least one citation and five documents (full count).

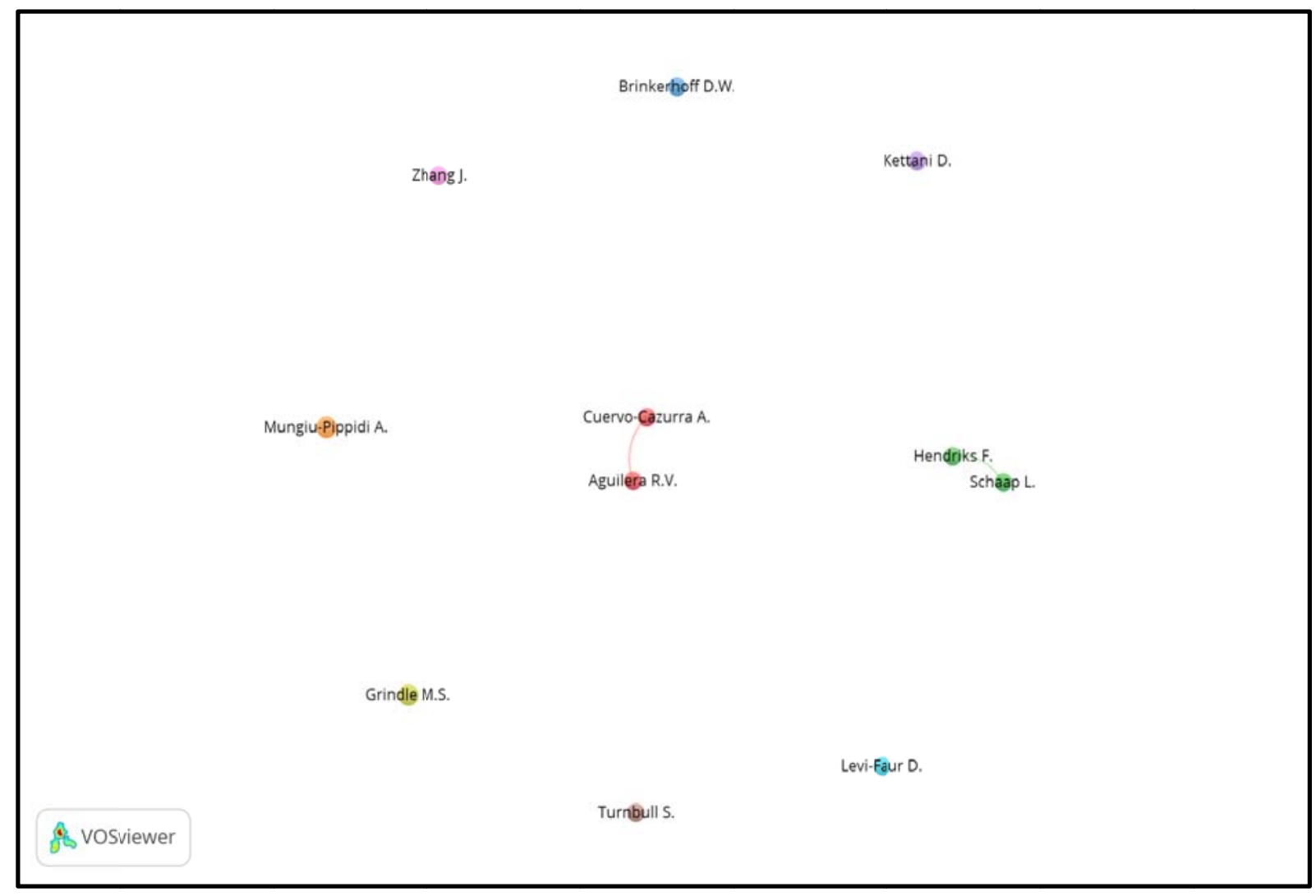

Source: VOSviewer

Figure 6. VOSviewer visualization of a term co-occurrence network based on the author 


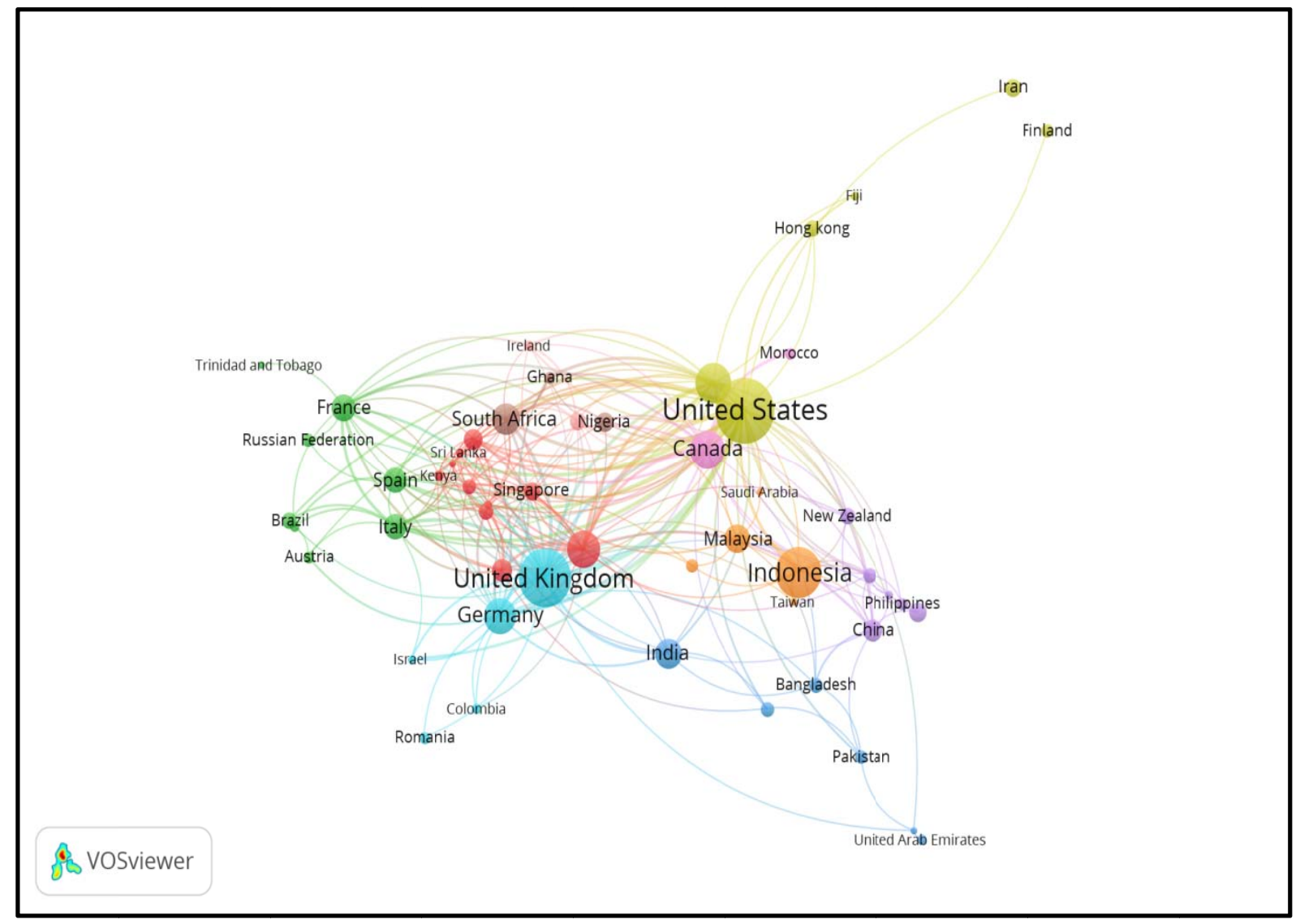

Source: VOSviewer

Unit of analysis $=$ Countries

Counting method: Full counting

Minimum number of documents of a country $=5$

Minimum number of citations of a country $=1$

Figure 7. Network visualization map of the co-authorship

\section{Most Influential Institutions}

The participation of research institutions related to good governance has also been taken into account in this paper, which is based on a minimum of nine publications. One hundred and sixty institutions have contributed to good governance's research. Table 12 shows the top 20 institutions with a minimum of nine publications. Two institutions from Malaysia are included in the top 20, namely Universiti Utara
Malaysia and Universiti Teknologi MARA, and three institutions from Indonesia, namely, Universitas Airlangga, Universitas Padjajaran, and Universitas Brawijaya. Meanwhile, the University of Toronto has the highest number of good governance publications with 17 publications (1.92), followed by Universiti Teknologi MARA with 16 publications (1.81\%) and Universiti Utara Malaysia is in the third position with 15 publications (1.69\%). 
Table 12. Most influential institutions with a minimum of nine publications

\begin{tabular}{lcc}
\hline \multicolumn{1}{c}{ Affiliation } & Total Publication & \% (N=885) \\
\hline University of Toronto & 17 & 1.92 \\
Universiti Teknologi MARA & 16 & 1.81 \\
Universiti Utara Malaysia & 15 & 1.69 \\
Universiteit van Amsterdam & 13 & 1.47 \\
KU Leuven & 13 & 1.47 \\
Universitas Airlangga & 13 & 1.47 \\
City University of Hong Kong & 11 & 1.24 \\
Erasmus Universiteit Rotterdam & 11 & 1.24 \\
Universitas Padjadjaran & 11 & 1.24 \\
Vrije Universiteit Amsterdam & 10 & 1.13 \\
National University of Singapore & 10 & 1.13 \\
University College London & 10 & 1.13 \\
University of Oxford & 10 & 1.13 \\
London School of Economics and Political Science & 9 & 1.02 \\
The University of Manchester & 9 & 1.02 \\
Tilburg University & 9 & 1.02 \\
University of Twente & 9 & 1.02 \\
University of Melbourne & 9 & 1.02 \\
University of Cambridge & 9 & 1.02 \\
Universitas Brawijaya & 9 & 1.02 \\
\hline
\end{tabular}

\section{Citation Analysis}

Table 13 summarizes the citation metrics for documents retrieved on November 4, 2020, at 7.58 am. As can be seen, there were 17,889 citations reported in the 36 years (1984 to 2020) of good governance publications. These citation metrics were created by Harzing's Publish or Perish software by importing a RIS formatted file from the Scopus database into the software to present the raw citation metrics.

Moreover, Table 14 demonstrates the top 10 most cited articles (based on the number of documents cited) according to the Scopus database. The document entitled "Good enough governance: Poverty reduction and reform in developing countries" by Grindle (2004), Harvard University affiliates, United States, has received the highest number of citations (471 citations or an average of 29.44 citations per year).

Table 13. Citations metrics

\begin{tabular}{lc}
\hline \multicolumn{1}{c}{ Metrics } & Data \\
\hline Publication years & $1984-2020$ \\
Citation years & $36(1984-2020)$ \\
Papers & 1,954 \\
Citations & 17,889 \\
Citations/year & 496.92 \\
Citations/paper & 9.16 \\
Citations/author & 112.51 \\
Papers/author & 12.29 \\
Authors/paper & 1.98 \\
h-index & 58 \\
g-index & 98 \\
\hline Source: Harzing's Publish or Perish
\end{tabular}


Table 14. Highly cited articles - Most influential papers

\begin{tabular}{|c|c|c|c|c|c|c|}
\hline No & Authors & Title & Year & Cites & $\begin{array}{c}\text { Cites Per } \\
\text { Year }\end{array}$ & $\begin{array}{c}\text { Cites Per } \\
\text { Author }\end{array}$ \\
\hline 1 & Grindle, 2004 & $\begin{array}{l}\text { Good enough governance: Poverty } \\
\text { reduction and reform in developing } \\
\text { countries }\end{array}$ & 2004 & 471 & 29.44 & 471 \\
\hline 2 & Lockwood, 2010 & $\begin{array}{l}\text { Good governance for terrestrial } \\
\text { protected areas: A framework, } \\
\text { principles and performance outcomes }\end{array}$ & 2010 & 270 & 27.00 & 270 \\
\hline 3 & Hood \& Heald, 2012 & $\begin{array}{l}\text { Transparency: The key to better } \\
\text { governance? }\end{array}$ & 2012 & 205 & 25.63 & 103 \\
\hline 4 & Bennett et al., 2019 & $\begin{array}{l}\text { Local support for conservation is } \\
\text { associated with perceptions of good } \\
\text { governance, social impacts, and } \\
\text { ecological effectiveness }\end{array}$ & 2019 & 25 & 25.00 & 4 \\
\hline 5 & Asongu et al., 2019 & $\begin{array}{l}\text { The mobile phone as an argument for } \\
\text { good governance in sub-Saharan Africa }\end{array}$ & 2019 & 24 & 24.00 & 6 \\
\hline 6 & $\begin{array}{l}\text { Brinkerhoff \& } \\
\text { Brinkerhoff, } 2011\end{array}$ & $\begin{array}{l}\text { Public-private partnerships: } \\
\text { Perspectives on purposes, publicness, } \\
\text { and good governance }\end{array}$ & 2011 & 209 & 23.22 & 105 \\
\hline 7 & $\begin{array}{l}\text { Aguilera \& Cuervo- } \\
\text { Cazurra, } 2004\end{array}$ & $\begin{array}{l}\text { Codes of Good Governance Worldwide: } \\
\text { What is the Trigger? }\end{array}$ & 2004 & 353 & 22.06 & 177 \\
\hline 8 & $\begin{array}{l}\text { Rodriguez- } \\
\text { Fernandez, } 2016\end{array}$ & $\begin{array}{l}\text { Social responsibility and financial } \\
\text { performance: The role of good } \\
\text { corporate governance }\end{array}$ & 2016 & 86 & 21.50 & 86 \\
\hline 9 & $\begin{array}{l}\text { Mungiu-Pippidi, } \\
2015\end{array}$ & $\begin{array}{l}\text { The quest for good governance: How } \\
\text { societies develop control of corruption }\end{array}$ & 2015 & 99 & 19.80 & 99 \\
\hline 10 & Grindle, 2007 & Good enough governance revisited & 2007 & 252 & 19.38 & 252 \\
\hline
\end{tabular}

\section{CONCLUSION AND SUGGESTION}

This study aimed to investigate trends and research developments in the field of good governance by using a bibliometric analysis. By adopting this method, the productivity of the research and publications in a particular domain can be evaluated (Moed et al., 2001). The bibliographic analysis results can provide information to evaluate a certain research domain's performance. Thus, agencies can formulate policies related to research funding allocations and compare the scientific input and output (Gu, 2004). Furthermore, the bibliometric analysis results can explain the factors that enhance the contribution of studies in the research area and guide scholars in producing impactful studies (Akhavan et al., 2016). This study indicates that the number of good governance publications has been increasing rapidly. It is believed that several research opportunities related to good governance are still attractive to researchers and the numbers will continue to grow in the future.

Nearly all the publications were written in English (95.04\%) by 159 authors from 123 countries. The United States and the United Kingdom are the top two countries that contributed to the publication of articles on good governance. Research into this subject is generally published in the social sciences group. 
Apart from focusing on the research fields of social sciences, business, management, accounting, economics, econometrics, and finance, studies on good governance are also carried out in the fields of environmental science, the arts and humanities, medicine, computer science, and engineering. The focus of these areas can be seen from the results of the analysis that VOSviewer processes with a keyword analysis and an analysis of the title and abstract.

The impact of publications about good governance can be seen from the citation metrics disclosed in this paper. Based on 36 years of publications (1984 to 2020), 1,954 documents have been published with a total of 17,889 citations. There are 496.92 citations per year, 9.16 citations per paper, and 112.51 authors per paper for documents collected from the Scopus database on good governance.

Although bibliometric analysis has a specific nature, however, this study has limitations that should be overcome to provide a clear understanding for the reader, and to improve the quality of any future research. First, the keywords used are specific only to good governance, based on the document's title. Thus, query search results in other fields such as the abstract and keywords, author, affiliates, and source title have not been included in this analysis. The main reason is that most of the research that focuses on a specific area will be included in the document's title. Some people may put terms related to the search query in the abstract or keywords. However, their research focus may not be specifically related to what the researchers are looking for. Therefore, screening and cleaning need to be carried out before the analysis begins. Future research can be expanded with other search queries.

Second, both positive and negative errors should be anticipated because there is no search query that is $100 \%$ perfect (Sweileh et al., 2017). Third, this study only focused on the Scopus database as the main source of document searches. Although Scopus is one of the most extensive databases for indexing scientific works (Ahmi \& Mohamad, 2019; Sweileh et al., 2017), Scopus does not cover all the available sources. Other available databases could be included in future research, such as Web of Science, Google Scholar, Dimension, and PubMed. Combining all of these databases may also contribute to more interesting and valuable results.

Apart from these limitations, this study has contributed to the current knowledge by presenting current good governance research trends. This study also expands and complements previous findings about the good governance literature using a bibliometric approach and provides meaningful insights about the past literature trends.

\section{REFERENCES}

Abdellatif, A. M. (2003). Good governance and its relationship to democracy and economic development. Global Forum III on Fighting Corruption and Safeguarding Integrity, 20 31.

Abdulazeez, S. A. (2014). Measuring good governance and sustainable development by statistical series and indicators. Journal of Physical Science and Innovation, 6(2), 2736.

Addink, H. (2019). Good governance: Concept and context. Oxford University Press.

Aguilera, R. V., \& Cuervo-Cazurra, A. (2004). Codes of good governance worldwide: What is the trigger? Organization Studies, 25(3), 415-443. https://doi.org/10.1177/0170840604040669

Ahmi, A., \& Mohamad, R. (2019). Bibliometric analysis of global scientific literature on web accessibility. International Journal of Recent Technology and Engineering, 7(6), 250-258. 
Akhavan, P., Ebrahim, N. A., Fetrati, M. A., \& Pezeshkan, A. (2016). Major trends in knowledge management research: A bibliometric study. Scientometrics, 107(3), 1249-1264. https://doi.org/10.1007/s11192016-1938-x

Asongu, S., le Roux, S., Nwachukwu, J. C., \& Pyke, C. (2019). The mobile phone as an argument for good governance in subSaharan Africa. Information Technology and People, 32(4), 897-920.

https://doi.org/10.1108/ITP-01-2018-0011

Bellis, N. De. (2009). Bibliometrics and citation analysis: From the science citation index to cybermetrics. Scarecrow Press, INC. https://doi.org/10.1016/c2014-0-00967-7

Bennett, N. J., Di Franco, A., Calò, A., Nethery, E., Niccolini, F., Milazzo, M., \& Guidetti, P. (2019). Local support for conservation is associated with perceptions of good governance, social impacts, and ecological effectiveness. Conservation Letters, 12(4), 2-11. https://doi.org/10.1111/conl.12640

Biswas, R., Jana, A., Arya, K., \& Ramamritham, K. (2019). A good-governance framework for urban management. Journal of Urban Management, 8(2), 225-236.

Brinkerhoff, D. W., \& Brinkerhoff, J. M. (2011). Public-private partnerships: Perspectives on purposes, publicness, and good governance. Public Administration and Development, 31(1), 2-14. https://doi.org/10.1002/pad.584

Brundtland, G. H. (1987). Report of the World Commission on Environment and Development: "Our common future."

Burris, S., Kempa, M., \& Shearing, C. (2008). Changes in governance: A crossdisciplinary review of current scholarship (41 Akron L. Rev. 1).

Daim, T. U., Rueda, G., Martin, H., \& Gerdsri, P. (2006). Forecasting emerging technologies: Use of bibliometrics and patent analysis. Technological Forecasting and Social Change, 73(8), 981-1012.

https://doi.org/10.1016/j.techfore.2006.04.0 04
Demmers, J., Fernandez, A. E., Jilberto, \& Hogenboom, B. (2004). Good governance and democrazy in a world of neoliberal regimes. In J. Demmers, A. E. Fernandez, Jilberto, \& B. Hogenboom (Eds.), Good governance in the era of global neoliberalism: Conflict and depolitisation in Latin America, Eastern Europe, Asia and Africa (pp. 1-37). Routledge.

Dhaoui, I. (2019). Good governance for sustainable development. In MPRA Paper No. 92544 (No. 92544). https://mpra.ub.unimuenchen.de/92544/

Dijkstra, G. (2018). Aid and good governance: Examining aggregate unintended effects of aid. Evaluation and Program Planning, 8, 225-232.

Fukuyama, F. (2013). What is governance? Governance, 26(3), 347-368. https://doi.org/10.1111/gove.12035

Fukuyama, F. (2016). Governance: What do we know, and how do we know it? Annual Review of Political Science, 19(1), 89-105. https://doi.org/10.1146/annurev-polisci042214-044240

Gisselquist, R. M. (2012). Good governance as a concept, and why this matters for development policy (2012/30).

Grindle, M. S. (2004). Good enough governance: Poverty reduction and reform in developing countries. Governance, 17(4), 525-548. https://doi.org/10.1111/j.09521895.2004.00256.x

Grindle, M. S. (2007). Good enough governance revisited. Development Policy Review, 25(5), 533-574.

https://doi.org/10.1111/j.14677679.2007.00385.x

Grindle, M. S. (2010). Good governance: The inflation of an idea (No. RWP10-023; HKS Faculty Research Working Paper Series).

Gu, Y. (2004). Global knowledge management research: A bibliometric analysis. Scientometrics, 61(2), 171-190.

https://doi.org/10.1023/B:SCIE.0000041647 $.01086 . f 4$ 
Hall, C. M. (2011). Publish and perish? Bibliometric analysis, journal ranking and the assessment of research quality in tourism. Tourism Management, 32(1), 1627.

https://doi.org/10.1016/j.tourman.2010.07.0 01

Ho, Y. S. (2007). Bibliometric analysis of adsorption technology in environmental science. Journal of Environmental Protection Science, 1(1), 1-11.

Hood, C., \& Heald, D. (2012). Transparency: The key to better governance? Oxford University Press.

Horvath, A. (2017). 'Governance'-in crisis? A cross-disciplinary critical review of three decades of 'governance' scholarship (No. 20).

Khouya, M., \& Benabdelhadi, A. (2020). Good governance and its impact on economic development: A systematic literature review. International Journal of Accounting, Finance, Auditing, Management and Economics, 1(1), 47-67.

Klusáček, P., Alexandrescu, F., Osman, R., Malý, J., Kunc, J., Dvořák, P., Frantál, B., Havlíček, M., Krejčí, T., Martinát, S., Skokanová, H., \& Trojan, J. (2018). Good governance as a strategic choice in brownfield regeneration: Regional dynamics from the Czech Republic. Land Use Policy, 73, 29-39.

https://doi.org/10.1016/j.landusepol.2018.01 .007

Lockwood, M. (2010). Good governance for terrestrial protected areas: A framework, principles and performance outcomes. Journal of Environmental Management, 91(3), 754-766.

https://doi.org/10.1016/j.jenvman.2009.10.0 05

Ma, Z. (2005). From theoretical essentials to paradigms: The development path of electronic commerce research. International Journal of Electronic Business, 3(5), 491. https://doi.org/10.1504/ijeb.2005.008522
Moed, H. F., Luwel, M., \& Nederhof, A. J. (2001). Towards research performance in the humanities. Library Trends, 50(3), 498520 .

Mohamoud, M. O. H. (2020). The conditionalities of aid and the good governance agenda: The World Bank and its member states. International Journal of Innovative Science and Research Technology, 5(5), 114-121.

Mungiu-Pippidi, A. (2015). The quest for good governance: How societies develop control of corruption.

https://doi.org/10.1017/CBO978131628693 7

Naomi, P., Akbar, I., \& Firmanzah. (2020). A bird's eye view of researches on good governance: Navigating through the changing environment. Webology, 17(2), 150-171.

Pomeranz, E. F., \& Stedman, R. C. (2020). Measuring good governance: piloting an instrument for evaluating good governance principles. Journal of Environmental Policy \& Planning, 22(3), 428-440.

Potter, W. G. (1981). Introduction to library trends. Library Trends, 30(1), 5-8.

Pritchard, A. (1969). Statistical bibliography or bibliometrics. Journal of Documentation, 25(5), 348-349.

Ramzy, O., Bedawy, R. El, Anwar, M., \& Eldahan, O. H. (2019). Sustainable development \& good governance. European Journal of Sustainable Development, 8(2), 125-125.

https://doi.org/10.14207/ejsd.2019.v8n2p12 5

Rodriguez-Fernandez, M. (2016). Social responsibility and financial performance: The role of good corporate governance. BRQ Business Research Quarterly, 19(2), 137-151. https://doi.org/10.1016/j.brq.2015.08.001

Rusly, F. H., Ahmi, A., Talib, Y. Y. A., \& Rosli, K. (2019). Global perspective on payroll system patent and research: A bibliometric 
performance. International Journal of Recent Technology and Engineering, 8(2 S2), 148-157.

https://doi.org/10.35940/ijrte.B1028.0782S2 19

Schiehll, E., \& Martins, H. C. (2017). Cross national governance research: A systematic review and assessment. Corporate Governance: An International Review, 24(3), 181-199.

Silal, P., Jha, A., \& Saha, D. (1984). From egovernment to good governance: The mediating role of government EParticipation. 40th International Conference on Information Systems, ICIS 2019.

Sweileh, W. M., Al-Jabi, S. W., AbuTaha, A. S., Zyoud, S. H., Anayah, F. M. A., \& Sawalha, A. F. (2017). Bibliometric analysis of worldwide scientific literature in mobile health: 2006-2016. BMC Medical Informatics and Decision Making, 17(72), 1-12. https://doi.org/10.1186/s12911-017-0476-7

Tarverdi, Y., Saha, S., \& Campbell, N. (2019). Governance, democracy and development.
Economic Analysis and Policy, 63, 220233.

United Nations Development Programme. (2015). Sustainable development goals.

Valenzuela, L. M., Merigó, J. M., Johnston, W. J., Nicolas, C., \& Jaramillo, J. F. (2017). Thirty years of the journal of business \& industrial marketing: A bibliometric analysis. Journal of Business and Industrial Marketing, 32(1), 1-18.

https://doi.org/10.1108/JBIM-04-2016-0079

van Eck, N. J., \& Waltman, L. (2010). Software survey: VOSviewer, a computer program for bibliometric mapping. Scientometrics, 84(2), 523-538.

https://doi.org/10.1007/s11192-009-0146-3

Zakaria, R., Ahmi, A., Ahmad, A. H., \& Othman, Z. (2021). Worldwide melatonin research: a bibliometric analysis of the published literature between 2015 and 2019. Chronobiology International, 3(1), 27-37. https://doi.org/10.1080/07420528.2020.183 8534. 